Primljen / Received: 8.9.2015.

Ispravljen / Corrected: 2.4.2016.

Prihvaćen / Accepted: 17.7.2016.

Dostupno online / Available online: 10.1.2017.

\section{Optimisation of railway track maintenance and renewal works by genetic algorithms}

Author:

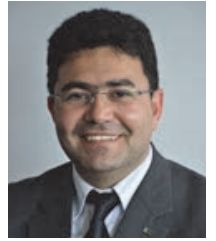

Assoc.Prof. Hakan Guler, PhD. CE

University of Sakarya, Turkey

Faculty of Engineering

Department of Civil Engineering

hguler@sakarya.edu.tr
Subject review

Hakan Guler

\section{Optimisation of railway track maintenance and renewal works by genetic algorithms}

This paper describes a new approach to optimisation of railway track maintenance and renewal works via genetic algorithms. Decision support systems and genetic algorithms are used in this study to optimise railway track maintenance and renewal activities. The results obtained in the scope of this study show that planned maintenance and renewal management systems can be developed and successfully used instead of resorting to corrective maintenance activities.

Key words:

track maintenance, optimisation, genetic algorithms, decision support systems, expert systems

Pregledni rad

Hakan Guler

Optimizacija održavanja i remonta željezničkih kolosijeka primjenom genetičkih algoritama

Rad opisuje novi pristup optimizaciji radova na održavanju i remontu željezničkih kolosijeka pomoću genetičkih algoritama. U istraživanju su primijenjeni sustavi za potporu u odlučivanju i genetički algoritmi radi optimizacije radova na održavanju i remontu željezničkih kolosijeka. Rezultati istraživanja su pokazali da je moguće razviti sustav za upravljanje radovima planskog održavanja i remonta te ga uspješno primijeniti umjesto korektivnih radova održavanja.

Ključne riječi:

održavanje kolosijeka, optimizacija, genetički algoritmi, sustavi podrške odlučivanju, ekspertni sustavi

Übersichtsarbeit

Hakan Guler

\section{Optimierung der Instandhaltung und Erneuerung von Eisenbahngleisen mit genetischen Algorithmen}

Diese Arbeit beschreibt einen neuen Ansatz bei der Optimierung von Instandhaltungsund Erneuerungsarbeiten von Eisenbahngleisen aufgrund genetischer Algorithmen. Bei den Untersuchungen wurden Systeme zur Entscheidungsunterstützung und genetische Algorithmen eingesetzt, um Instandhaltungs- und Erneuerungsarbeiten von Eisenbahngleisen zu optimieren. Die Resultate haben gezeigt, dass es möglich ist, ein System für die Verwaltung planmäßiger Instandhaltungs- und Erneuerungsarbeiten zu entwickeln und ihn erfolgreich als Ersatz für korrektive Instandhaltungsarbeiten anzuwenden.

Schlüsselwörter:

Instandhaltung von Gleisen, Optimierung, genetischer Algorithmus,

Entscheidungsunterstützungssysteme, Expertensystem 


\section{Introduction}

Every year, railway organisations spend large amounts of money for rail track maintenance and renewal works to ensure proper serviceability of the railroad network. According to statistics, average annual maintenance and renewal (M\&R) expenditures per $1 \mathrm{~km}$ of tracks revolve around $€ 50.000$ for West-European networks. For that reason, it is essential to properly understand behaviour of every single railway infrastructure element to keep the railway infrastructure in a satisfactory condition, [1]. Railway organizations generally use different M\&R techniques depending on their existing facilities. Generally, there are two types of interventions during the lifetime of a railway system. These are corrective maintenance and preventive maintenance activities. Railway organizations realize corrective maintenance whenever a failure happens, such as replacement of a broken railway track component. Preventive maintenance is realized periodically according to a pre-determined schedule, such as ballast cleaning or integral renewal. However, railway organizations use traditional methods targeting corrective maintenance. Generally the track geometry and components are monitored and afterwards the track components are renewed when they deteriorate, the aim being to achieve the required quality level. As a result, the quality of railway investment and maintenance, which is the only key factor for railways, is ignored. The quality of railway investment and maintenance means that the operator is able to identify, schedule and plan capital work, maintenance and renewal activities. The responsibility stays with the infrastructure operator, who should manage the implementation effectively. Track maintenance and renewal works carried out at the right time are crucial to realize an efficient and optimized maintenance and renewal work plans, and hence to increase the life of track components. As railway tracks get older the maintenance and renewal costs increase exponentially. The efficiency of railway systems can therefore be increased by cost reduction and better control of maintenance processes. A modern railway infrastructure maintenance management system requires a diagnostic concept, meaning a condition-based approach, as well as the criticality and urgency analyses of all key infrastructure components. Railway organizations can achieve an efficient maintenance and renewal management situation by performing an optimization between maintenance and renewal works, as well as an optimization enabling achievement of spatial and temporal coherence of the works. Several mathematical models for railways can be used to achieve effective and efficient maintenance. The development of the application tool technology (involving both software and hardware) has enabled development of the decision support systems (DSS) incorporating new computational maintenance optimization models such as genetic algorithms (GA). Decision support systems are technologies that enable provision of accurate knowledge to accurate decision makers, at accurate times, in accurate form, and at accurate costs. A proper decision support system helps asset managers in making the best decision with regards to financial limitations and other dominant constraints imposed upon the problem at hand [2]. A decision support system is a computer-based system that represents and processes knowledge in the ways that allow decision making to be more productive, agile, innovative, and/or reputable [3]. Over the years, it has been proven that the decision making procedure has been mostly represented as if-then-else rules depending on the nature of the decision support system. The rules are developed by relevant experts and the working procedure of the system is incorporated in expert systems. The quality of the decision support system depends on both the quality and extent of knowledge contained in the system [4]. Over the years, considerable progress has been made in developing railway track M\&R planning systems, not only by railway organizations, but also by specialist institutes and universities. These research activities have been carried out in the U.S., Canada, Japan, and Europe. More detailed information can be found in ERRI D 187/RP 1 report [5, 6]. In addition, Deluka-Tibljas et al. (2013) considered the complex issue of making transport infrastructure decisions in urban areas. They analysed the use of multicriteria-analyses in this process. The analyses were carried out by a multicriteria-analysis technique. The analyses covered the planning, design, maintenance, and rehabilitation of transport infrastructure. Finally, the authors presented conclusions on the possibilities, advantages, and limitations of the use of multicriteriaanalysis methods, with the purpose of improving quality of decision making regarding transport infrastructure in urban areas [7].

Nonlinear mixed integer models are difficult to solve. Soft computing based approaches have been commonly used to deal with such issues. In this article, a genetic algorithm (GA) is proposed to optimize railway track M\&R Works. The GA is a strategy that models the mechanics of genetic evolution. Main characteristics of the GA are based on the principles of adaptation and survival of the fittest [8]. GAs are a kind of numerical optimisation algorithms inspired by both natural selection and genetic recombination. The method can be applied to an extremely wide range of problems. The algorithms are simple to understand and the required computer code is easy to write. A possible solution to a problem is referred to as an individual. An individual is represented by a computational data structure called a chromosome encoded using a fixed length alphabet. Species are individuals with a common characteristic, and niches are subdomains of the search space. By encouraging niching and speciation, GAs can facilitate simultaneous convergence to more than one optimum in a multimodal search space [9]. Literature studies have shown that the track maintenance work plans are generally generated using deterministic methods. There are also a few examples of different track maintenance planning techniques. For instance, Grimes (1995) planned track maintenance work using genetic algorithm (GA) and Genetic Programming (GP) methods, with profit as the optimisation criterion. Grimes compared the results with an existing deterministic technique. It was established that the GP method gives the best results, with the GA method giving good results for a short section, and poor results for a long section of track [10]. Milajic et al. (2011) described the methodology for using genetic algorithms in solving problems of optimum assignment of tasks to construction machinery operators, aimed at achieving 
maximum efficiency. A special emphasis is placed on the influence of human factor (operator competence) on the efficiency of the system [11].

More specifically, an optimisation of railway track M\&R works by genetic algorithms is described in the paper. The developed system is basically a condition-based system that uses measured data gathered on the track. The system analyses the track using its comprehensive database, which includes decision rules developed by the track specialist professionals. The developed system is a kind of expert system that uses human information and knowledge captured in computer to handle a problem. Thus, the development of an expert system can effectively help engineers to control and analyse such problems.

In this study, a Turkish State Railways (TCDD) railway track between Arifiye and Eskisehir, $180 \mathrm{~km}$ in length, was taken into consideration, and the suggested model was used. The railway track between Arifiye and Eskisehir was divided into 720 "analytical segments" (AS). The proposed genetic algorithm based decision support system was implemented as an optimisation tool, and positive results were obtained.

\section{Developed system approach}

The applications and basic techniques of the developed system are described in this chapter. The developed system is a condition based decision support system that contains a rich M\&R rule database, through which decisions are made as to which and what kind of M\&R works are necessary for the railway track. In this study, track M\&R works envisaged by TCDD were investigated and the most important M\&R works were defined by considering Turkish railway experts' knowledge and experience in cases when required data were unavailable. For this purpose, the TCDD railway experts shared their knowledge and experience for the design and the development of this system. The survey experts were selected from the TCDD General Directorate, regions, divisions, and subdivisions.
The participants were a mixed group of engineers and technicians, most of them working at the TCDD track department. Based on the expert decisions, the railway maintenance and renewal activities given in Table 1 were considered. These works were classified as "maintenance" and "renewal" and an appropriate abbreviation was assigned to each activity.

Track class, track layout, operational data such as speeds and axial tonnage, reference values and limits, number of trains, loads and cumulative loads, age, material types, condition of substructure, M\&R history, measurements such as track geometry, accelerations and noise, number of failures, number of damaged components, condition indices, service indices, standard deviations, statistical distributions, costs etc. were defined by experts as parameters to develop decision rules for each type of M\&R activity.

Some of the parameters based on analytical segments (AS) and maintenance segments (MS) are calculated by the developed system. The analytical segments (AS) were created by considering railway track properties such as the type of rail, gradient, speed, etc. Maintenance sections (MS) were constituted by combining series of analytical segments. These data, both inputs and outputs, are used within the M\&R rule algorithms. However some further intermediate data were sometimes produced in the process. During the rules' development process, three main levels, namely the Alert Limit (AL), Intervention Limit (IL), and Immediate Action Limit (IAL), were considered. The detailed information on limit values can be found in the following sections. Simple rules were defined for each type of M\&R operation by using relevant data. For example: IF Track Data (1) $\geq$ Limit value (1) OR Track Data (2) $\geq$ Limit value (2) OR Track Data (3) $\geq$ Limit value (3) ... THEN Work type, Date. Uncertainties arising from the lack of knowledge on threshold values were also eliminated using expert judgement [6]. The system structure of the developed model is presented in Figure 1. Generally, the principal objective is to identify the M\&R requirements in order to classify them into appropriate categories [5]. Similarly, the developed system provides analyses in five stages.

Table 1. Classification of track maintenance and renewal activities

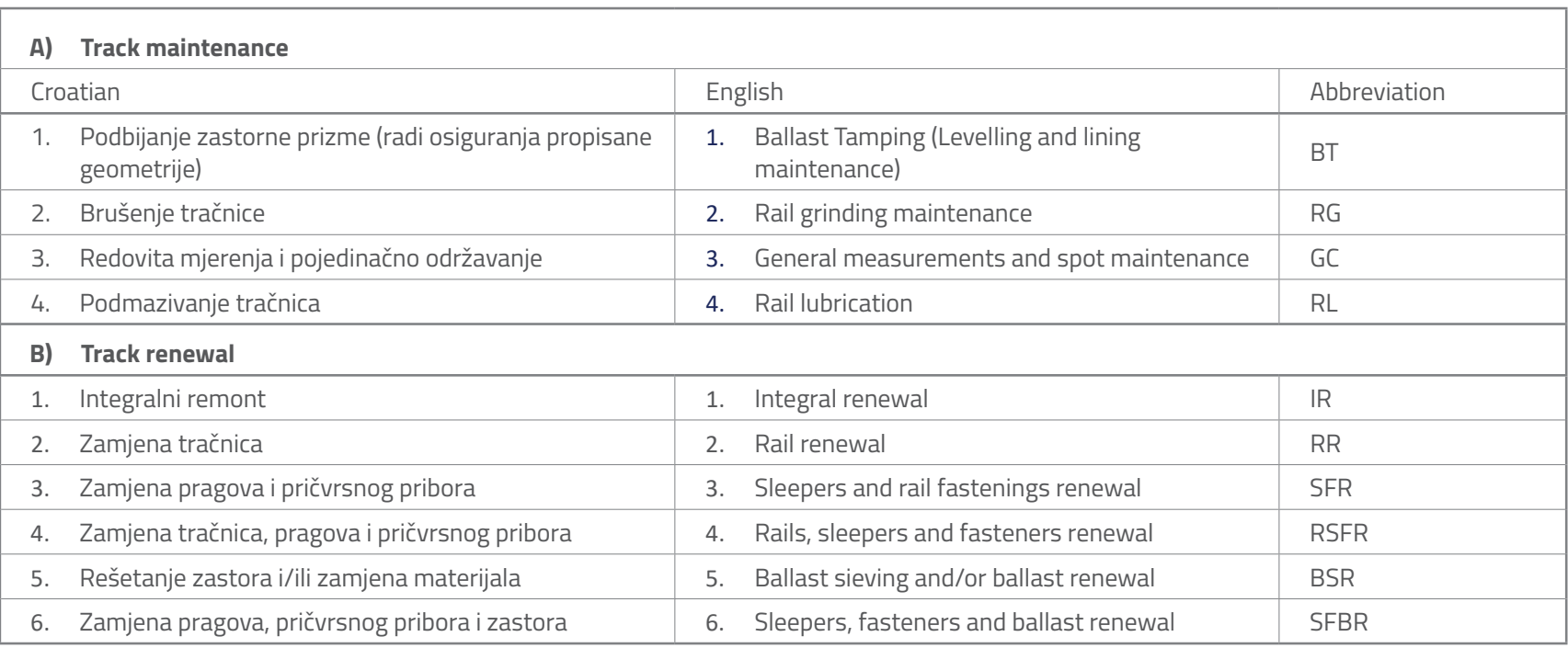


In the first stage of the system, the railway network data is simply evaluated based on a minimum amount of data, and the track is effectively classified into FOUR M\&R classes:

- M\&R class I: Sections do not require any M\&R because threshold values are below AL. These sections are examined at the coherence stage.

- M\&R class II: Sections require regular M\&R operations because threshold values are between $\mathrm{AL}$ and IL.

- M\&R class III: Sections may require corrective maintenance and/or renewal operations because threshold values are between IL and IAL. These sections are examined in detail at the second stage.

- M\&R class IV: Railway traffic is prohibited. Sections may require corrective maintenance and/or renewal operations because threshold values exceed IAL. These sections are examined in detail at the second stage.

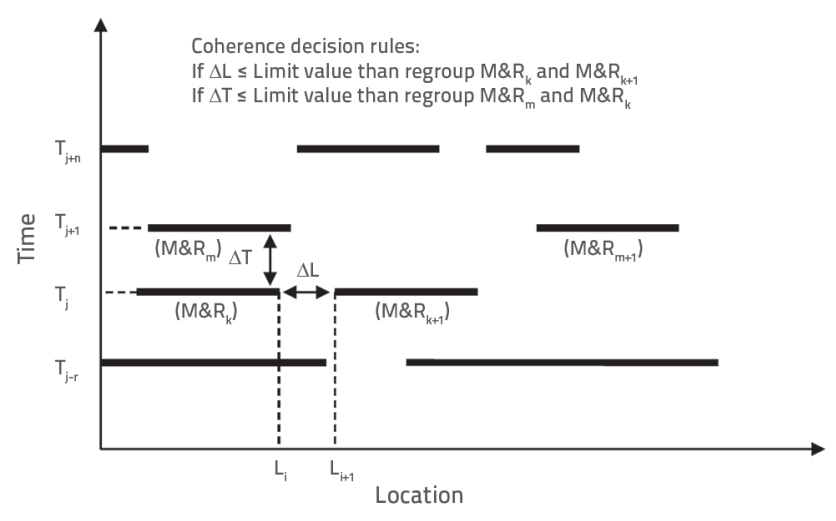

Figure 2. Coherence rules' procedure

In the second stage, the ASs and MSs are comprehensively analysed to determine the necessary M\&R works and their respective urgency. This stage is based on detailed data,

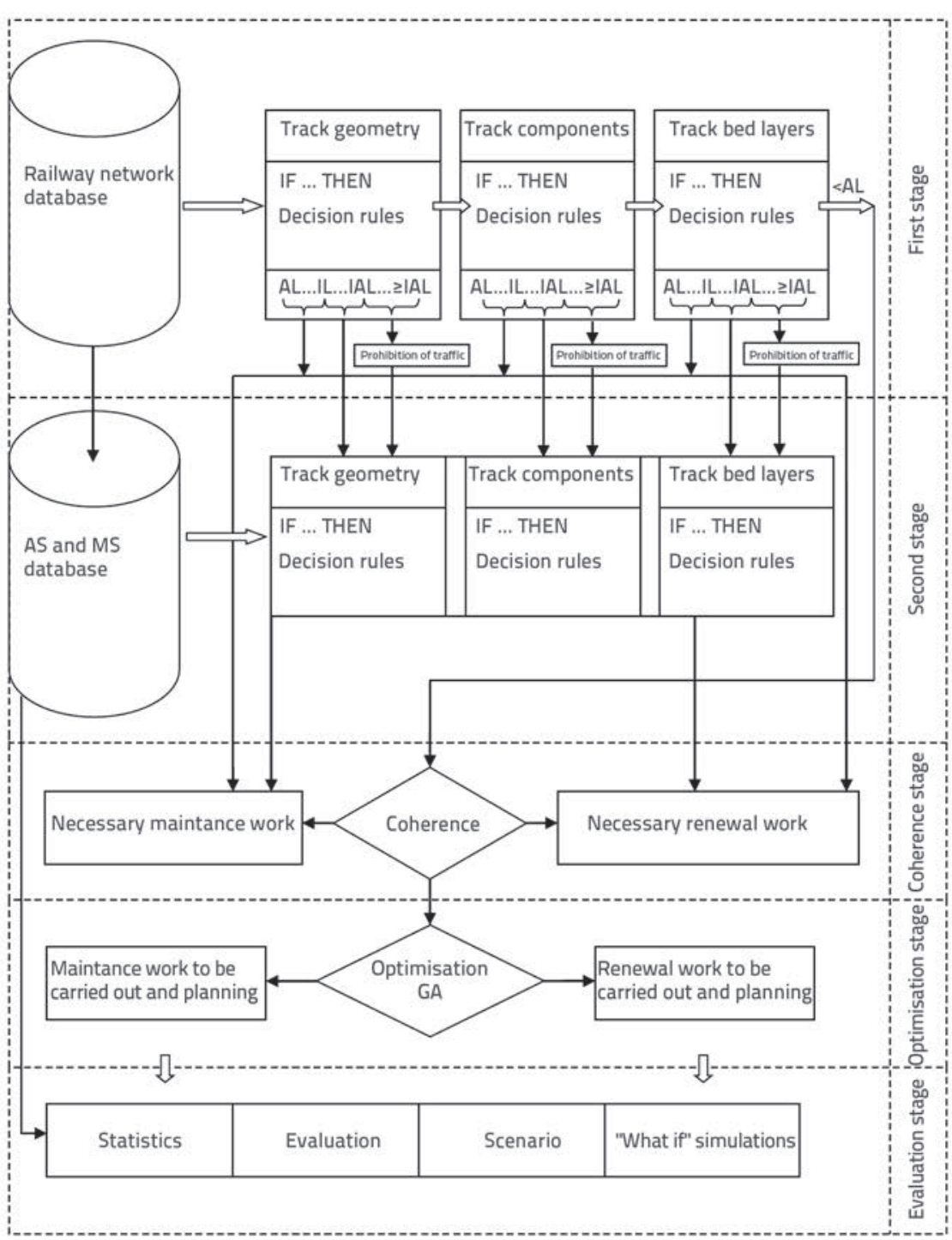

Figure 1. System structure which are threshold values, decision rules and deterioration models, and M\&R predictions are made for medium and long periods. The development of decision rules for railway track components is presented in Chapter 4.

The third stage of the system is reserved for coherence analyses based on the decision rules about the time and space coherence between the M\&R operations during the following and planned years. Two main classes of coherence rules were considered: time bounded rules and location bounded rules. The time bounded rules group together maintenance or renewal work depending on location. The location bounded rules group together maintenance or renewal work depending on time. These two main classes of coherence rules are shown in Figure 2.

The fourth stage of the system is the optimisation stage. At this stage, genetic algorithms are used to produce optimal M\&R works. This stage takes the result of the coherence stage and assesses the technical and economic feasibility of the M\&R operations, taking into account various managerial and resource allocation constraints. This stage enables users to proceed to the final M\&R planning based on technical constraints (machines, staff, and time) and economical constraints (funds for M\&R works) provided by the systems. The system proposed 


\begin{tabular}{|c|}
\hline FRONT END \\
\hline Measurements \\
\hline Rules \\
\hline Constrains \\
\hline
\end{tabular}
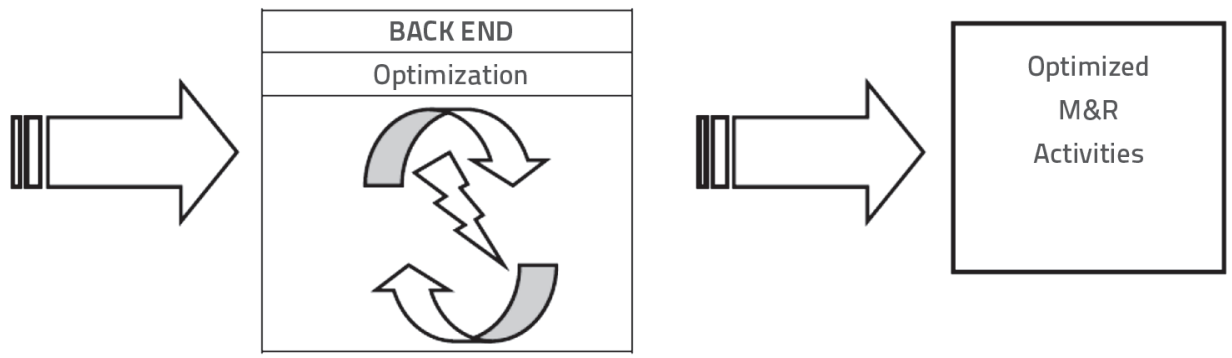

Figure 3. Optimisation stage design

in this study calculates the cost of works taking into account equations given in Section 4.5. The system is also capable of producing calculations on the discounted cash flow method. During the optimisation procedure, different types of maintenance and renewals works are regrouped due to some economic constraints (i.e. sleepers and fastenings renewal work is regrouped with rail renewal or vice versa.). The interaction between M\&R works due to some technical constraints (i.e. rail grinding is moved just after sleepers and fastenings renewal work) is also considered in this stage. The system design is presented in Figure 3. A detailed explanation of the application

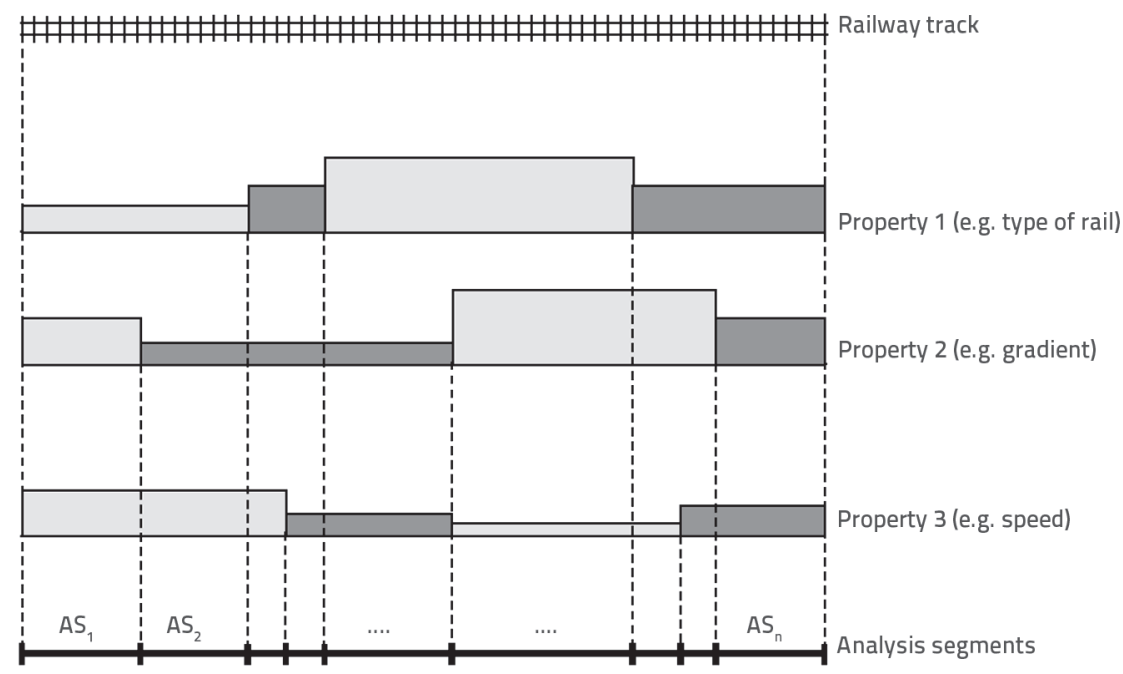

Figure 4. Track segmentation process

of genetic algorithms at the optimization stage of the system is provided in Section 4.

The fifth stage is the final evaluation stage. The evaluation stage of the system provides the users with the data needed for the overall management of M\&R operations of the railway network. The obtained optimal M\&R works can be compared with the associated risks estimated at this stage. The organizational performance or the capacity of the railway organisation can also be examined at the evaluation stage. Scenarios analyses, which are an integral part of situation analysis and long-range planning, enable operators to estimate probable effects of one or more variables. This stage enables full use of track data and obtained results in statistical analyses, "What if ?" simulations applied to track quality, definition of track life cycle costs, budgeting, M\&R policies, etc.

\section{Decision rules for track maintenance and renewal}

The decision rules were developed on the basis of standards (BS EN 13848, BS EN 13450, UIC 719 and UIC 714), deterioration models, and expert decisions. Track geometry and track components, i.e. rails, sleepers, and track bed layers, and their maintenance or/and renewal threshold values, are described on the basis of analytical segments.

Track data are generally extracted from basic units of sections, which are known as "analytical segments" (AS). The segmentation process used in this study is explained in Figure 4. Track recording cars store the data along the track, and then these data are collected into small maintenance sections (MS). Measurement, inspections, works carried out, and infrastructure data, are obtained for every MS. Finally, the information needs further aggregating into longer "route" sections to enable Network-scale assessment of the quality and consequential M\&R needs [14].

\subsection{Track geometry}

The quality of track geometry is defined by assessing deviations from the mean or designed geometrical characteristics of specified parameters in the vertical and lateral planes [14]. The track geometry exerts an influence on all track components and their service lives [15]. In this study, three indicators are taken into account to describe the quality of track geometry: extreme values of isolated defects, standard deviation over a defined length (AS), and mean value over AS.

Track quality indicators relating to comfort, reliability and safety must be calculated and checked with predefined limit values. Any excess of the limit values must result in an intervention. 
Three main levels were therefore considered during the rules development procedures: Alert Limit ( $A L)$, Intervention Limit (IL) and Immediate Action Limit (IAL):

- Alert Limit ( $\boldsymbol{A} \mathbf{L})$ : If the AL is exceeded then the track geometry condition is analysed and considered in the regularly planned maintenance operations.

- Intervention Limit (IL): If the IL is exceeded then required corrective maintenance actions are carried out so that the immediate action limit is not reached before the next inspection.

- Immediate Action Limit (IAL): If the IAL is exceeded then required measures are taken to reduce the risk of derailment to an acceptable level.

Three main levels of track geometry parameters were defined separately according to EN 13848-5 in terms of three indicators [16]. Besides track geometry parameters, other parameters contributing to vehicle track interaction and ride quality were also considered during the M\&R rule development. These parameters are obtained by direct measurement or derived measurement:

- Parameters obtained by direct measurement: horizontal curvature $(1 / \mathrm{m})$, vertical curvature $(1 / \mathrm{m})$, gradient $(\mathrm{mm} / \mathrm{m})$, and acceleration $\left(\mathrm{m} / \mathrm{s}^{2}\right)$.

- Parameters obtained by derived measurement: change of gradient $(\mathrm{mm} / \mathrm{m})$, rate of change of gradient $\left(\mathrm{mm} / \mathrm{m}^{2}\right)$, cant deficiency $(\mathrm{mm})$, Rate of change of cant deficiency $(\mathrm{mm} / \mathrm{s})$, cant deficiency variation $(\mathrm{mm})$, rate of change of cant $(\mathrm{mm} / \mathrm{s})$, cant gradient $(\mathrm{mm} / \mathrm{m})$, cant variation $(\mathrm{mm})$, ride index.

- Supporting data: line speed $(\mathrm{km} / \mathrm{h})$, distance measurement (m).

Accelerations of bogies and vehicle floor are important data for rail grinding or rail renewal decisions, as well as for running safety and ride comfort of railway vehicles. Threshold values for the accelerations currently used at TCDD are given in Table 2 [17].

Table 2. Accelerations

\begin{tabular}{|l|c|c|c|c|}
\hline Accelerations & Unit & AL & IL & IAL \\
\hline Transverse acceleration of bogie & $\mathrm{m} / \mathrm{s}^{2}$ & 5,00 & 7,50 & 10,00 \\
\hline Transverse acceleration of train floor & $\mathrm{m} / \mathrm{s}^{2}$ & 2,50 & 3,25 & 3,75 \\
\hline Vertical acceleration of train floor & $\mathrm{m} / \mathrm{s}^{2}$ & 2,50 & 3,25 & 3,75 \\
\hline
\end{tabular}

A numerical quality index is required to represent the condition of track geometry. A review of available literature shows that various railway organizations use different approaches for development of track geometry indexes [18]. The main condition indices are calculated based on detailed track inspection via recording car measurements. In this study, the Q-value is calculated as shown in $[17,19]$, equation (1):
$Q I=150-\frac{100}{3} \cdot\left[\frac{\sigma_{H}}{\sigma_{H L i m}}+2 \cdot \frac{\sigma_{I}}{\sigma_{\text {ILim }}}\right]$

where:

QI - Condition index

$\sigma_{H} \quad$ - Average standard deviation of height,

$\sigma_{\perp} \quad$ - Average standard deviation of interaction

$\sigma_{\text {HLim }}$ i $\sigma_{\text {ILim }}$ - Comfort limits for a given track class.

The standard deviation of interaction is calculated as a combined effect of the cant and the side position of the rail. The $C$ value is calculated for a longer track section and is expressed as presented in [17, 19], equation (2):

$C=\frac{\sum_{i} u_{i}}{T U} \cdot 100$

where:

C - Condition index

TU - Total length of track considered

$\sum_{i} u_{i}$ - sum of track length where all the $\sigma$ values are below the comfort limits for a given track class [17].

The values of QI and C coefficients exceeding the intervention limits are given in Table 3. These condition indices were considered during the M\&R rule development.

Table 3. Condition indices

\begin{tabular}{|l|c|c|c|}
\hline Condition indices & AL & IL & IAL \\
\hline QI & $<80$ & $<50$ & $<40$ \\
\hline C & $<80$ & $<30$ & $<10$ \\
\hline
\end{tabular}

\subsection{Rails}

Railway track M\&R activities always involve rail renewal because of breakages or damage resulting from traffic load, time, and/or manufacturing defects. The following data were gathered to monitor behaviour of rails: general information, accurate location of defect in the track, date, defect detection method, characteristics of line and track, characteristics of rail, characteristics of welds or resurfacing, code number of defect, action taken, and description of failures.

Three definitions, i.e. damaged rails, cracked rails and broken rails, were used for rail defects in accordance with the UIC 712 rail defect coding system [20]. For M\&R operations, the following expressions were used to make the recommendations more easily understandable by maintenance staff:

- Keep rail under inspection (AL),

- Removal of the rail (IL),

- Prohibition of traffic and immediate removal of the rail (IAL).

Rail measurements obtained from various sources and the rail failure limit values were transferred into the developed DSS's database. These are: rail headwear $(\mathrm{mm})$, side wear $(\mathrm{mm})$, head 
profile, gauge corner profile, rail inclination, rail corrugation (mm) and equivalent conicity.

Based on the failure evaluation method (visual testing, ultrasonic testing, etc.), limit values for rail failures were defined with the appropriate operational interventions (speed restrictions, operational restrictions, etc.), and these values were then transferred into the developed DSS's database.

Previous studies have shown that rail fatigue defects follow a Weibull's law. 2-parameter Weibull distribution has been used in this study to analyse the data and to predict the rail failure rate as it has the ability to provide reasonably accurate failure analysis and prediction [21, 22]:

$$
F(M)=1-\exp \left[-(M / \eta)^{\beta}\right]
$$

where:

$\mathrm{F}(\mathrm{M})$ - Cumulative rail failure distribution

M - Cumulative load (or time)

h - Scale parameter

$\beta$ - Shape parameter.

The shape parameter $\beta$ has an effect on the failure rate of a component. The scale parameter $\eta$ is also known as the characteristic life of a component. The decisions rules were developed based on $\beta$ and $\eta$ parameters, as shown in Table 4 [21].

Table 4. Weibull distribution parameters for rails

\begin{tabular}{|l|c|l|}
\hline Parameter & Value & Decision \\
\hline Shape parameter $(\beta)$ & $<1$ & Infant mortality stage \\
\hline Shape parameter $(\beta)$ & 1 & Random failures \\
\hline Shape parameter $(\beta)$ & $>1$ & $\begin{array}{l}\text { Wear-out stage of the } \\
\text { component }\end{array}$ \\
\hline Scale parameter $(\eta)$ & $\geq 1$ & $\begin{array}{l}\text { More than } 63.2 \% \text { of the unit } \\
\text { failed }\end{array}$ \\
\hline
\end{tabular}

Lubrication of wheel flanges and rails is an effective solution for reducing wear loss of material from cross-section of rail and wheels, especially at sharp curves. Generally, annual grease consumption for rail lubrication ranges between 0.7 and $2.5 \mathrm{~kg} / \mathrm{km}$. In this study, the following parameters were adopted as decision rules for rail lubrication: number of trains, track curvature, number of rail failures, cumulative loads, and Weibull distribution parameters.

\subsection{Sleepers}

Decisions related to sleepers are based on the data stored in the database (age, type, tonnage, etc.), geometry measurements by track recording cars, and results of visual assessment of sleepers. In Turkey, railway sleeper visual inspections are currently performed manually by human operators, i.e. a railway worker walks along the track and visually examines each sleeper, $[17,23]$.

Two most frequent defects of concrete sleepers are cracks and surface defects (TCDD 2009). The wooden and concrete sleeper condition data for TCDD network are presented in Tables 5 and 6, respectively. The studies carried out on different track constructions show that the wear/damage of wooden and concrete sleepers is insignificant over a relatively long time, but that it increases very fast in the final period. Thus, this phenomenon is strongly non-linear in character.

The exponential distribution is a frequently used distribution in reliability engineering. It is used to model the behaviour of units having a stable failure rate. Mathematically, the one-parameter exponential probability density function (pdf) is given by [24] expression (4):

$f(t)=\lambda e^{-\lambda t}$

where:

$f(t)$ - density function

$\lambda$ - scale parameter (hazard rate)

t $\quad$ time.

The one-parameter exponential cumulative density function $(F(t)$ or $c d f)$ is given by expression (5):

$F(t)=1-e^{-\lambda t}$

The one-parameter exponential reliability $(R(t))$ function is given by expression (6):

$R(t)=e^{-\lambda t}$

General condition of sleepers may be defined as a Present Serviceability Index (PSI). In this study, the one parameter exponential cdf was modified and the following equation was used to determine the PSI value for sleepers $[5,17]$ :

$P S I(M)=1-\exp \left[k_{f}\left(\frac{M}{M_{L}}-1\right)\right]$

where:

M - cumulative load or time

$M_{L}$ - cumulative load or age limit

$\mathrm{k}_{\mathrm{f}}$ - age (or cumulative load) adjustment factor.

The PSI values were also taken into account during the M\&R operations for sleepers. The PSI values were obtained from statistical analyses and expert decisions. The limit PSI values are given in Table 7, where parameters required to calculate the PSI value are also given. 
Table 5. Inspection criteria for wooden sleepers

\begin{tabular}{|c|l|l|}
\hline $\begin{array}{c}\text { Damage } \\
\text { level }\end{array}$ & Damage status & Decision \\
\hline $\mathbf{1}$ & $\begin{array}{l}\text { Widely cracked, steel plate is } \\
\text { sunken }\end{array}$ & $\begin{array}{l}\text { Replacement within } \\
3 \text { weeks }\end{array}$ \\
\hline $\mathbf{2}$ & $\begin{array}{l}\text { Not widely cracked, steel } \\
\text { plate is sunken }\end{array}$ & $\begin{array}{l}\text { Replacement within } \\
12 \text { weeks }\end{array}$ \\
\hline $\mathbf{3}$ & $\begin{array}{l}\text { Presence of cracks, steel } \\
\text { plate is not sunken }\end{array}$ & Condition monitoring \\
\hline $\mathbf{4}$ & $\begin{array}{l}\text { No cracks, steel plate in not } \\
\text { sunken }\end{array}$ & No action \\
\hline
\end{tabular}

Table 6. Inspection criteria for concrete sleepers

\begin{tabular}{|c|c|c|}
\hline $\begin{array}{l}\text { Damage } \\
\text { level }\end{array}$ & Damage status & Decision \\
\hline 1 & $\begin{array}{l}\text { Severe damage (widely } \\
\text { cracked) }\end{array}$ & $\begin{array}{l}\text { Replacement within } \\
3 \text { weeks }\end{array}$ \\
\hline 2 & $\begin{array}{l}\text { Severe damage (long cracks) } \\
\text { - longitudinal } \geq 0,3 \mathrm{~mm} \\
\text { - } \text { at dowel } \geq 0,1 \mathrm{~mm} \\
\text { - } \text { at head } \geq 0,3 \mathrm{~mm} \\
\text { - transverse } \geq 0,3 \mathrm{~mm}\end{array}$ & $\begin{array}{l}\text { Replacement within } \\
12 \text { weeks }\end{array}$ \\
\hline 3 & Damage & Condition monitoring \\
\hline 4 & Light surface damage & No action \\
\hline
\end{tabular}

Table 7. Railway sleepers: PSI values with required parameters

\begin{tabular}{|c|c|c|c|c|}
\hline $\begin{array}{l}\text { Type of } \\
\text { sleepers }\end{array}$ & $\begin{array}{l}\text { Traffic load } \\
\text { [MGT/year] }\end{array}$ & $\begin{array}{c}\text { Coefficient } \\
\left(\mathbf{k}_{\mathrm{f}}\right)\end{array}$ & $\begin{array}{l}\text { Life time } \\
\text { [godine] }\end{array}$ & $\begin{array}{l}\text { Decision } \\
\text { (concrete, hard } \\
\text { and soft timber) }\end{array}$ \\
\hline Concrete & $>15$ & 5,2 & 35 & \multirow{6}{*}{$\begin{array}{l}0,6<P S \mid \leq 1,0 \text { : } \\
\text { only maintenance } \\
0,4<P S \mid \leq 0,6 \text { : } \\
\text { partial } \\
\text { replacement } \\
0,2<\mathrm{PSI} \leq 0,4 \text { : } \\
\text { planning of } \\
\text { renewal } \\
\text { 0,0 } \leq \mathrm{PSI} \leq 0,2 \text { : } \\
\text { renewal }\end{array}$} \\
\hline Concrete & $\leq 15$ & 5,2 & 40 & \\
\hline $\begin{array}{l}\text { Hard } \\
\text { timber }\end{array}$ & $>15$ & 5,2 & 25 & \\
\hline $\begin{array}{l}\text { Hard } \\
\text { timber }\end{array}$ & $\leq 15$ & 5,2 & 30 & \\
\hline $\begin{array}{c}\text { Soft } \\
\text { timber }\end{array}$ & $>15$ & 5,2 & 18 & \\
\hline $\begin{array}{c}\text { Soft } \\
\text { timber }\end{array}$ & $\leq 15$ & 5,2 & 21 & \\
\hline
\end{tabular}

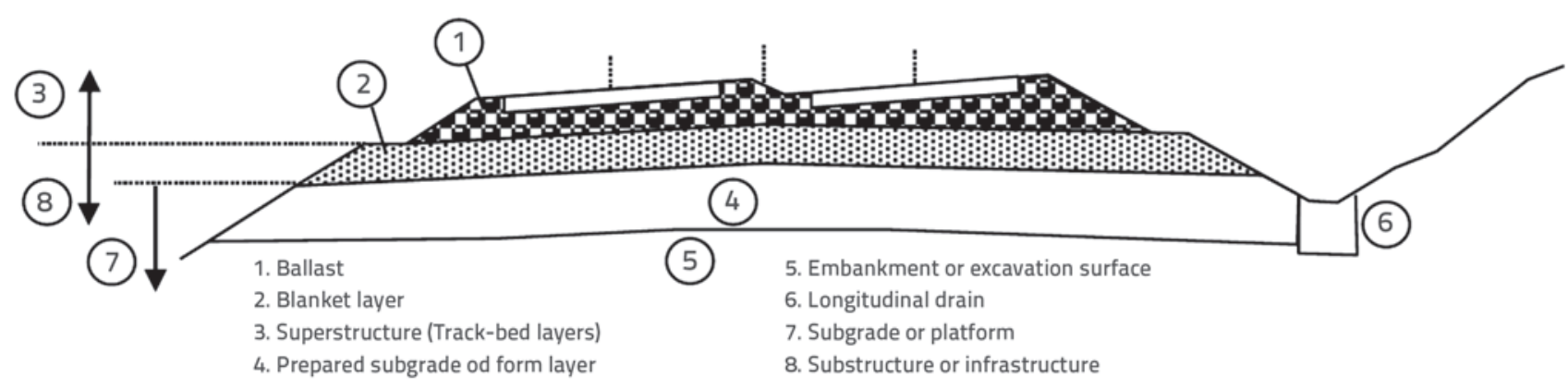

Figure 5. Schematic cross section of railway track

Track bed layers have an important role in track performance, namely with respect to track support stiffness, maintenance of track geometry, and drainage. The general term of track bed layer refers to both ballast and sub-ballast layers. In this study, Figure 5 was considered for track structure during the data collecting process.

Terms such as general maintenance, renewal, routine maintenance, remedial works, strengthening and improvements of railway track bed, were used to define maintenance of earthworks and track bed on existing lines. Earthwork is a general term applying to cuttings, embankments and composite cross sections. In this study, the substructure was classified according to following terms: Geotechnical classification of soils, Classification of soils according to bearing capacity and frost susceptibility of soils [25].

A good quality ballast must be made of well-graded aggregates. However, over time, the presence of dust and fine particles in ballast layer leads to track settlement and drainage problems. Reference values for ballast and sub-ballast are given in Table 8. These values were considered when making the M\&R decisions. In addition, the ballast standard, which is EN 13450, was taken into consideration during development of decision rules [26].

Table 8. Reference values for ballast and sub-ballast

\begin{tabular}{|l|c|c|c|c|c|c|}
\hline Materijl & $\begin{array}{c}\text { E } \\
{[\mathrm{MPa}]}\end{array}$ & $v$ & $\begin{array}{c}\mathbf{c} \\
{[\mathrm{MPa}]}\end{array}$ & $\begin{array}{c}\varphi \\
{\left[{ }^{\circ}\right]}\end{array}$ & $\begin{array}{c}\gamma \\
{\left[\mathrm{kN} / \mathrm{m}^{3}\right]}\end{array}$ & $\begin{array}{c}\text { Minimum } \\
\text { depth } \\
{[\mathrm{mm}]}\end{array}$ \\
\hline Zastor & 130 & 0.2 & 0 & 45 & 15 & 300 \\
\hline Posteljica & 120 & 0.3 & 0 & 35 & 19 & 150 \\
\hline \\
$\begin{array}{l}\text { Where: E - modulus of elasticity, } v \text { - Poisson coefficient, } \\
\text { c- cohesion, } \varphi \text { - friction angle and } \gamma \text { - specific weight. }\end{array}$ \\
\hline
\end{tabular}

The annual average number $\left(/_{m}\right)$ of tamping operations can be statistically calculated as a function of track age for a given category of traffic. Thus a curve describing the annual average number increasing over time $(f(T))$ can be presented as follows:

$\ell_{m}=f(T)$ 
The number of tamping operations $(\ell)$ for a given age may differ from the annual average number $\left(\ell_{m}\right)$ of tamping operations. In this situation, the track bed maintenance coefficient $(k)$ for a particular track section can be defined as:

$k=\frac{\ell}{\ell_{m}}$

When $\ell$ exceeds a certain threshold value $\left(\ell_{s}=6\right)$, then track geometry standards can no longer be fully maintained; it will then be necessary to carry out other work in order to bring down the $k$ value, $[25,27]$. The track bed maintenance coefficient $k$ is known at all times because detailed records are kept about levelling operations. Factor $k$ reaches higher values if foundations are very poor. However, in average cases, the value of this coefficient is considered to be equal to one. This value and other observations made during line inspections determine the measures that are required for: routine maintenance, any localised actions, and renewals. Limit values for $k$ and relevant decisions are given in Table 9.

Table 9. Track bed maintenance coefficient

\begin{tabular}{|l|l|}
\hline Limits [k] & Decision \\
\hline $\mathrm{k}<1$ & Correct track bed layers \\
\hline $1<\mathrm{k}<2,5$ & Track bed layers slightly under-dimensioned \\
\hline $2,5<\mathrm{k}<5$ & $\begin{array}{l}\text { Under-dimensioned track bed layers, sub-ballast } \\
\text { layers of poor quality and poor functioning of } \\
\text { drainage }\end{array}$ \\
\hline $\mathrm{k}>5$ & $\begin{array}{l}\text { Track bed layers under-dimensioned, sub-ballast } \\
\text { layers of poor quality or non-existent and poor } \\
\text { functioning of drainage }\end{array}$ \\
\hline
\end{tabular}

\subsection{Life cycle costs}

The life-cycle cost (LCC) takes into account all costs associated with the life time of the system, such as operating costs, maintenance costs, energy costs, and taxes apart from capital costs [28]. The LCC is an effective engineering tool for providing decision support in the design, procurement and maintenance of major systems. Consequently, the LCC analyses were included into the developed system.

Curves with different radii and engineering structures (tunnels, bridges etc.) were considered in this study to associate maintenance costs with railway track. Railway tracks are exposed to lateral forces in curves. Consequently, the deterioration rate is higher in sharp curves and the replacement of track components occurs too frequently. Thus, the railway track was divided into different maintenance sections depending on the curve radius, i.e. 0-200 m ( $\left.R_{c}=1\right), 200-400 m\left(R_{c}=2\right)$, 400$600 \mathrm{~m}\left(\mathrm{R}_{\mathrm{c}}=3\right)$, and so on. Curves with the radius of more than $1800 \mathrm{~m}$ were considered as straight track. A number of each M\&R activities over a defined period was calculated considering cumulative traffic loads and interval values defined by expert decisions. For instance, $M / M_{\mathrm{RGi}}$ corresponds to the number of rail grinding actions over a time period. In this equation, $M$ is the cumulative load (or time) and $\mathrm{M}_{\mathrm{RGi}}$ is the interval for grinding of $i^{\text {th }}$ curve in MGT. $M_{\mathrm{RGi}}$ was defined considering parameters such as geographic condition, weather, curvature, etc., which were playing different roles in the formulation of LCC equations.

Even when railway track components are in good condition, engineering structures may be partially or completely damaged by various reasons such as leakage, cracks, fatigue, etc. In such situations, damaged engineering structures must be repaired during the required M\&R activity. So, an additional cost was added to the total cost to take into account the engineering structure. The M\&R costs were determined according to simplified TCDD calculations. Relevant calculations are shown below, [17, 28]:

\section{Rail grinding cost}

$R G C=\sum_{s=1}^{S} \sum_{i=1}^{R} \sum_{j=1}^{N-1} \frac{\left(C_{R G s}+\left(T_{R G i} \cdot C_{L} \cdot L_{i} \cdot n_{R G i}\right)+\left(T_{R G i} \cdot C_{E R G} \cdot L_{i} \cdot n_{R G i}\right)\right) \cdot\left(M / M_{R G i}\right)}{(1+r)^{j}}$

where:

$C_{R G s}$ - additional grinding cost due to $\mathrm{s}^{\text {th }}$ engineering structure, [TL]

$\mathrm{T}_{\mathrm{RGi}}$ - average time to grind $\mathrm{i}^{\text {th }}$ curve, $[\mathrm{h} / \mathrm{km}]$

$C_{L} \quad$ - average labour cost, $[T L / h]$

$\mathrm{n}_{\mathrm{RGi}}$ - number of grinding passes on $\mathrm{i}^{\text {th }}$ curve

$C_{E R G}$ - equipment cost for grinding, $[T L / h]$

$\mathrm{M}_{\mathrm{RGi}}$ - interval for grinding of $\mathrm{i}^{\text {th }}$ curve, [MBT]

M - cumulative load (or time)

$L_{i} \quad$ - total length of maintenance section, [km]

$r$ - discount rate

$S$ - number of engineering structures

$\mathrm{R}$ - number of curve radius classes

$\mathrm{N}$ - life period of track in years.

\section{Rail lubrication cost}

$R L C=\sum_{s=1}^{S} \sum_{i=1}^{R} \sum_{j=1}^{N-1} \frac{\left(C_{R L S}+\left(T_{R L i} \cdot C_{L} \cdot L_{i}\right)+\left(T_{R L i} \cdot C_{E R L} \cdot L_{i}\right)\right) \cdot\left(M / M_{R L i}\right)}{(1+r)^{j}}$

where:

$C_{R L s}$ - additional rail lubrication cost due to $s^{\text {th }}$ engineering structure, [TL]

$T_{R L i}$ - average time to lubricate $i^{\text {th }}$ curve, [h/ $\left.\mathrm{km}\right]$

$C_{L}$ - average labour cost, [TL/h]

$C_{E R L}$ - equipment and material cost for lubricating, [TL/h]

$\mathrm{M}_{\mathrm{RLi}}$ - interval for lubricating of $\mathrm{i}^{\text {th }}$ curve, [MBT]

M - cumulative load (or time)

$\mathrm{L}_{\mathrm{i}} \quad$ - total length of maintenance section, [km]

$r$ - discount rate

$S$ - number of engineering structures

$\mathrm{R}$ - number of curve radius classes

$\mathrm{N}$ - life period of track in years.

\section{Rail renewal cost}

$R R C=\sum_{s=1}^{S} \sum_{i=1}^{R} \sum_{j=1}^{N-1} \frac{\left(C_{R R s}+\left(C_{R} \cdot L_{i}\right)+\left(T_{R R i} \cdot C_{L} \cdot L_{i}\right)+\left(T_{R R i} \cdot C_{E R R} \cdot L_{i}\right)\right) \cdot\left(M / M_{R R i}\right)}{(1+r)^{j}}$ 
where:

$C_{R R s}$ - additional rail renewal cost due to $s^{\text {th }}$ engineering structure, [TL]

$C_{R}$ - cost of rail, [km/TL]

$C_{L}$ - average labour cost, $[\mathrm{TL} / \mathrm{h}]$

$C_{E R R}$ - equipment cost for rail renewal, [TL/h]

$T_{R R i}$ - average time for rail renewal of $\mathrm{i}^{\text {th }}$ curve, [h/km]

$M_{R R i}$ - interval for rail renewal for $i^{\text {th }}$ curve, $[M B T]$

$\mathrm{M}$ - cumulative load (or time)

$L_{i} \quad$ - total length of maintenance section, [km]

$r$ - discount rate

$S$ - number of engineering structures

$\mathrm{R}$ - number of curve radius classes

$\mathrm{N}$ - life period of track in years.

\section{Tamping cost}

$T C=\sum_{s=1}^{S} \sum_{i=1}^{R} \sum_{j=1}^{N-1} \frac{\left(C_{T s}+\left(T_{T i} \cdot C_{L} \cdot L_{i}\right)+\left(T_{T i} \cdot C_{E T} \cdot L_{i}\right)\right) \cdot\left(M / M_{T i}\right)}{(1+r)^{j}}$

where:

$\mathrm{C}_{\mathrm{Ts}}$ - additional tamping cost due to $\mathrm{s}^{\text {th }}$ engineering structure, [TL]

$C_{L}$ - average labour cost, $[\mathrm{TL} / \mathrm{h}]$

$\mathrm{C}_{\mathrm{ET}}$ - quipment cost for tamping, $[\mathrm{TL} / \mathrm{h}]$

$\mathrm{T}_{\mathrm{Ti}}$ - average time to tamp $\mathrm{i}^{\text {th }}$ curve, [h/km]

$\mathrm{M}_{\mathrm{Ti}}$ - interval for tamping of $\mathrm{i}^{\text {th }}$ curve, [MBT]

M - cumulative load (or time)

$L_{i} \quad$ - total length of maintenance section, [km]

$r$ - discount rate

$\mathrm{S}$ - number of engineering structures

$\mathrm{R}$ - number of curve radius classes

$\mathrm{N}$ - life period of track in years.

\section{Ballast renewal cost}

$B R C=\sum_{s=1}^{S} \sum_{i=1}^{R} \sum_{j=1}^{N-1} \frac{\left(C_{B R s}+\left(C_{B} \cdot L_{i}\right)+\left(T_{B R i} \cdot C_{L} \cdot L_{i}\right)+\left(T_{B R i} \cdot C_{E B R} \cdot L_{i}\right)\right) \cdot\left(M / M_{B R i}\right)}{(1+r)^{j}}$

where:

$\mathrm{C}_{\mathrm{BRs}}$ - additional ballast renewal cost due to $\mathrm{s}^{\text {th }}$ engineering structure, [TL]

$C_{B}$ - average labour cost, $[\mathrm{km} / \mathrm{TL}]$

$C_{L}$ - average labour cost, [TL/h]

$C_{E B R}$ - equipment cost for ballast renewal, [TL/h]

$T_{B R i}$ - average time for ballast renewal of $\mathrm{i}^{\text {th }}$ curve, [h/ $\left.\mathrm{km}\right]$

$\mathrm{M}_{\mathrm{BRi}}$ - nterval for ballast renewal for $i^{\text {th }}$ curve, [MBT]

$\mathrm{M}$ - cumulative load (or time)

$L_{i} \quad$ - total length of maintenance section, [km]

$r$ - discount rate

$\mathrm{S}$ - number of engineering structures

$\mathrm{R}$ - number of curve radius classes

$\mathrm{N}$ - life period of track in years.

\section{Ballast cleaning cost}

$B C C=\sum_{s=1}^{S} \sum_{i=1}^{R} \sum_{j=1}^{N-1} \frac{\left(C_{B C S}+\left(T_{B C i} \cdot C_{L} \cdot L_{i}\right)+\left(T_{B C i} \cdot C_{E B C} \cdot L_{i}\right)\right) \cdot\left(M / M_{B C i}\right)}{(1+r)^{j}}$ where:

$C_{B C s}$ - additional ballast cleaning cost due to $s^{\text {th }}$ engineering structure, [TL]

$C_{L} \quad$ - average labour cost, [TL/h]

$\mathrm{C}_{\mathrm{EBC}}$ - quipment cost for ballast cleaning, $[\mathrm{TL} / \mathrm{h}]$

$\mathrm{T}_{\mathrm{BCi}}$ - average time to clean ballast $\mathrm{i}^{\text {th }}$ curve, $[\mathrm{h} / \mathrm{km}]$

$\mathrm{M}_{\mathrm{BC}}$ - interval for ballast cleaning of $\mathrm{i}^{\text {th }}$ curve, [MBT]

M -cumulative load (or time)

$L_{i} \quad$ - total length of maintenance section, [km]

$r$ - discount rate

$\mathrm{S}$ - number of engineering structures

$\mathrm{R}$ - number of curve radius classes

$\mathrm{N}$ - life period of track in years.

\section{Sleeper renewal cost}

$S R C=\sum_{s=1}^{S} \sum_{i=1}^{R} \sum_{j=1}^{N-1} \frac{\left(C_{S R S}+\left(C_{S} \cdot L_{i}\right)+\left(T_{S R i} \cdot C_{L} \cdot L_{i}\right)+\left(T_{S R i} \cdot C_{E S R} \cdot L_{i}\right)\right) \cdot\left(M / M_{S R i}\right)}{(1+r)^{j}}$

where:

$\mathrm{C}_{\mathrm{SRS}}$ - additional sleeper renewal cost due to $\mathrm{s}^{\text {th }}$ engineering structure, [TL]

$\mathrm{C}_{\mathrm{s}}$ - cost of sleeper, [km/TL]

$C_{L}$ - average labour cost, [TL/h]

$C_{E S R}$ - equipment cost for sleeper renewal, $[\mathrm{TL} / \mathrm{h}]$

$T_{S R i}$ - average time for sleeper renewal for $i^{\text {th }}$ curve, [h/km]

$\mathrm{M}_{\mathrm{SRi}}$ - interval for ballast renewal of $\mathrm{i}^{\text {th }}$ curve, [MBT]

M - cumulative load (or time)

$L_{i} \quad$ - total length of maintenance section, [km]

$r \quad$ - discount rate

$\mathrm{S}$ - number of engineering structures

$\mathrm{R}$ - number of curve radius classes

$\mathrm{N}$ - life period of track in years.

\section{Fastener renewal cost}

$F R C=\sum_{s=1}^{S} \sum_{i=1}^{R} \sum_{j=1}^{N-1} \frac{\left(C_{F R S}+\left(C_{F} \cdot L_{i}\right)+\left(T_{F R i} \cdot C_{L} \cdot L_{i}\right)+\left(T_{F R i} \cdot C_{E F R} \cdot L_{i}\right)\right) \cdot\left(M / M_{F R i}\right)}{(1+r)^{j}}$

where:

$C_{\mathrm{FRs}}$ - additional fastener renewal cost due to $\mathrm{S}^{\text {th }}$ engineering structure, $[\mathrm{TL}]$

CF - cost of fastener, [km/TL]

$C_{L}$ - average labour cost, [TL/h]

$C_{\mathrm{EFR}}$ - equipment cost for fastener renewal [TL/h]

$\mathrm{T}_{\mathrm{FRi}}$ - average time for fastener renewal for $\mathrm{i}^{\text {th }}$ curve, [h/ km]

$\mathrm{M}_{\mathrm{FRi}}$ - interval for fastener renewal for $\mathrm{ith}^{\text {th }}$ curve, [MBT]

$M$ - cumulative load (or time)

$L_{i} \quad$ - total length of maintenance section, [km]

$r$ - discount rate

$\mathrm{S}$ - number of engineering structures

$\mathrm{R}$ - number of curve radius classes

$\mathrm{N}$ - life period of track in years.

Track inspection cost

$T / C=\sum_{s=1}^{S} \sum_{j=1}^{N-1} \frac{\left(C_{T I S}+\left(\left(T_{T l} \cdot C_{L} \cdot L\right)+\left(T_{T l} \cdot C_{E T l} \cdot L\right)\right) \cdot\left(M / M_{T I}\right)\right.}{(1+r)^{j}}$ 
where:

$\mathrm{C}_{\mathrm{Tls}}$ - additional track inspection cost due to $\mathrm{s}^{\text {th }}$ engineering structure [TL]

$C_{L} \quad$ - average labour cost [TL/h]

$\mathrm{C}_{\mathrm{ETI}}$ - equipment cost for track inspection $[\mathrm{TL} / \mathrm{h}]$

$\mathrm{T}_{\mathrm{TI}}$ - average time to inspect track [h/km]

$\mathrm{M}_{\mathrm{Ti}}$ - interval for track inspection [MBT]

M - cumulative load (or time)

$L_{i} \quad$ - total length of maintenance section, [km]

$r$ - discount rate

$\mathrm{S}$ - number of engineering structures

$\mathrm{R}$ - number of curve radius classes

$\mathrm{N}$ - life period of track in years.

\section{Genetic algorithms for track maintenance and renewal}

As presented previously, the railway line is generally divided into analytical segments (AS) for track geometry deterioration models. In addition, these segments are combined to constitute longer sections called maintenance sections. The analitical segments were considered as genes and maintenance sections were considered as chromosome structures. Genetic algorithms work by setting a population of chromosomes, which is a set of potential solutions to the optimization problem. A chromosome structure is basically an abstract representation of a railroad. Every railroad section matches a gene (part of a chromosome) in the chromosome structure (Figure 6).

The following data were collected for each analytical segment: track structure, traffic characteristics, track layout, environmental factors, and track geometry and maintenance and renewal data. The developed system produced M\&R activities for each analytical segment on the basis of developed rules. Each gene in a chromosome consists of a list of maintenance or renewal operations for that section. The chromosomes consist of numbers "1" and " 0 ". If the AS requires a maintenance or renewal activity then it assumes the value of "1", otherwise it is "0" (Figure 7).
Maintenance section

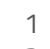

2

3

4
Chromosome structure

$[1,0,1,0,1,1,0,0, \ldots]$

$[0,1,1,1,1,0,1,1, \ldots]$

$[0,0,0,1,0,0,0,1, \ldots]$
$[1,1,0,0,1,1,0,0, \ldots]$

Figure 7. Chromosome structure
Optimization is the process of adjusting the inputs to characteristics of a device, mathematical process, or experiment to find the minimum or maximum output or result (Figure 8). The input consists of variables; the process or function is known as the cost function, objective function, or fitness function; and the output is the cost or fitness.

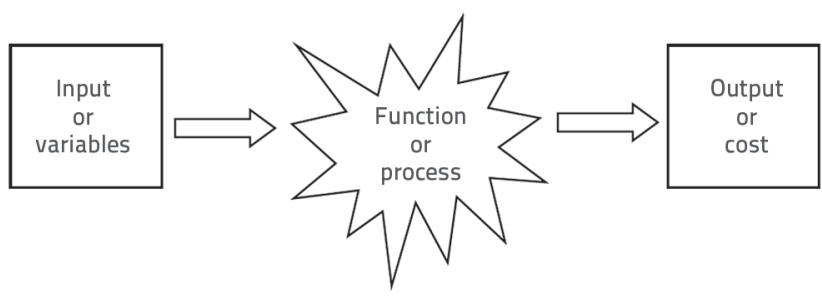

Figure 8. Optimisation process

The fitness is defined in such a way that highly fitted strings have high fitness values, and it is used to evaluate every individual in a population. It should be noted that fitness is the only link between genetic algorithms and the problem to be solved, and it is the measure for selecting an individual to reproduce for the next generation $[12,13]$.

In maximization problems such as the maximization of some profit or utility function $u(x)$, if $u(x)<0$ for some $x$, by introducing $C_{\min }$ and satisfying $u(x)+C_{\min }>0$, the fitness functions should be defined as $f(s)=u(x)+C_{\min }$. However, the value of $C_{\min }$ is not known in advance; $C_{\min }$ may be taken as the absolute value of the smallest $u(x)$ value observed thus far, in the current population, or the $t$ generations. Hence, in maximization problems the fitness of a string $s$ is defined as [12] equation

$f(s)=\left\{\begin{array}{l}u(x)+C_{\min }, \text { if } \cdot u(x)+C_{\min }>0 \\ 0, \ldots \ldots \ldots \ldots \ldots \text { othervise }\end{array}\right.$

where:

$f(s)$ - fitness function

$u(x)$ - utility function

$C_{\min }$ - cost function.

The fitness function design was conducted according to the distance to the actual solution. The actual solution was calculated from previously mentioned measurement values and railroad rules. Measurement values were used as input parameter to the rules, and every rule was applied to every railroad section to get the actual result. The resulting ideal

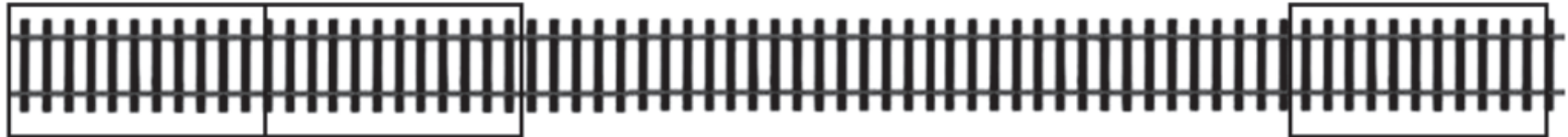

1

2

Figure 6. Analytical segments (genes) and maintenance section (chromosome structure) 
solution list is one of the most important inputs of the fitness function. This list is used to compare individual chromosomes and calculate the distance between the actual solution and a randomly generated chromosome. In Figure 9, the fitness $\left(\mathrm{N}_{\mathrm{i}}\right)$ corresponds to the number of M\&R activities.

\begin{tabular}{|ccc|}
\hline Maintenance section & Chromosome structure & Fitness \\
1 & {$[1,0,1,0,1,1,0,0, \ldots]$} & $N_{1}$ \\
2 & {$[0,1,1,1,1,0,1,1, \ldots]$} & $N_{2}$ \\
3 & {$[0,0,0,1,0,0,0,1, \ldots]$} & $N_{3}$ \\
4 & {$[1,1,0,0,1,1,0,0, \ldots]$} & $N_{4}$ \\
$\ldots$ & $\ldots \ldots \ldots \ldots \ldots \ldots \ldots \ldots \ldots . .$. & $\ldots$ \\
\hline
\end{tabular}

Figure 9. Fitness function

The GA begins with a group of chromosomes known as the population. The population is an abstract representation of the solution space. Population members are randomly filled chromosome structures.

The reproduction or selection is conducted to select the individuals in the population who will create offspring for the next generation, and to define how many offspring each will create. There are many ways in which this can be implemented. A commonly used method is the so called roulette selection, originally proposed by Holland [13]. The basic idea is to determine selection probability for each individual proportional to the fitness value. Namely, in roulette selection, the fitness $f_{i}(\geq 0), i=1, \ldots$, $n$ of each individual $i$ and the whole sum $\sum_{i=1}^{n} f_{\text {, }}$ is calculated. The selection probability, or survival probability of each individual $i$, is determined as [13] equation

$p_{i}=\frac{f_{i}}{\sum_{j=1}^{n} f_{j}}$

where:

$\mathrm{P}_{\mathrm{i}}$ - probability of $\mathrm{i}^{\text {th }}$ individual

$f_{i}-i^{\text {th }}$ fitness value

$f_{j}-j^{\text {th }}$ fitness value

$\mathrm{n}$ - number of individuals.

The population size has a direct effect on the solution and performance of the system. High population size results in higher accuracy of results, but the performance is lower. If the population size is reduced, the result may not be accurate but the performance will increase.

\begin{tabular}{|c|c|c|}
\hline Chromosome & & Crossover \\
\hline$[0,1, \mid 1,1,1,0,1,1]$ & $\rightarrow$ & {$[0,1, \mid \mathbf{0 , 0}, \mathbf{1}, \mathbf{1}, \mathbf{0}, \mathbf{0}]$} \\
\hline$[1,1, \mid \mathbf{0}, \mathbf{0}, \mathbf{1}, \mathbf{1}, \mathbf{0}, \mathbf{0}]$ & $\rightarrow$ & {$[1,1, \mid 1,1,1,0,1,1]$} \\
\hline$[0,0,0,1, \mid 0,0,0,1]$ & $\rightarrow$ & {$[0,0,0,1, \mid 1,0,1,1]$} \\
\hline$[0,1,1,1, \mid \mathbf{1}, \mathbf{0}, \mathbf{1}, \mathbf{1}]$ & $\rightarrow$ & {$[0,1,1,1, \mid \mathbf{0}, 0,0,1]$} \\
\hline
\end{tabular}

Figure 10. Crossover operation

The crossover operation is used to create new generations from existing individuals. This is used to combine the best properties of every gene in one chromosome. This operation is especially done by swapping one or more genes of the chromosomes. A crossover operation is designed to maximize the fitness value of the child chromosome (Figure 10).

After the crossover operation, the fitness function is executed on the resulting child chromosome. The calculated fitness value is compared with the existing fitness values in the population. If the child chromosome has lower fitness value compared to other existing chromosomes, then the child is discarded from the population. Otherwise, the chromosome stays in the population to create new individuals.

The mutation operation is implemented after the crossover operation. The aim of the mutation operation is to modify the randomly chosen properties of the existing chromosome structure. This operation aims to prevent the solution from getting stuck in a local minima. It is not applied to all chromosomes. Mutation chromosomes are chosen randomly from the population.

A couple of genes of an individual generated through crossover are changed in order to prevent the results. In Figure 11, a gene which undergoes the mutation process appears as a result of the mutation of randomly chosen genes of the individual generated through crossover. This design is used in order to avoid misleading results by preventing decrease to local minimum in populations having big numbers of chromosomes. Mutation process is not implemented for each and every individual. This process is conducted randomly on some chromosomes, i.e. all individuals are not allowed to undergo the mutation process.

\begin{tabular}{|ccc|}
\hline Chromosome & & \\
{$[0,1,0,0,1,1,0,0]$} & $\rightarrow$ & {$[0,1,0,1,1,1,0,0]$} \\
{$[1,1,1,1,1,0,1,1]$} & $\rightarrow$ & {$[1,1,1,1,1,0,1,1]$} \\
{$[0,0,0,1,1,0,1,1]$} & $\rightarrow$ & {$[0,0,0,1,1,0,1,1]$} \\
{$[0,1,1,1,0,0,0,1]$} & $\rightarrow$ & {$[0,1,1,1,0,0,0,0]$} \\
\hline
\end{tabular}

Figure 11. Mutation operation

\section{Case study}

The developed system was successfully implemented at TCDD with the help of local personnel. The required data were transferred into the system database from the existing databases and data collection systems. General properties of the analysed railway tracks are presented in Table 10.

Table 10. Properties of analysed railway tracks

\begin{tabular}{|l|l|}
\hline Track properties & Arifiye-Eskisehir \\
\hline Maximum speed [km/h] & 120 \\
\hline Total length [km] & 180 \\
\hline Minimum curve radius [m] & 256 \\
\hline Maximum axle load [t] & 22 \\
\hline Maximum gradient $[\%]$ & 27,55 \\
\hline Rail type & S49 \\
\hline Sleeper type & Wooden and concrete \\
\hline Rail length & Jointed and CWR \\
\hline
\end{tabular}




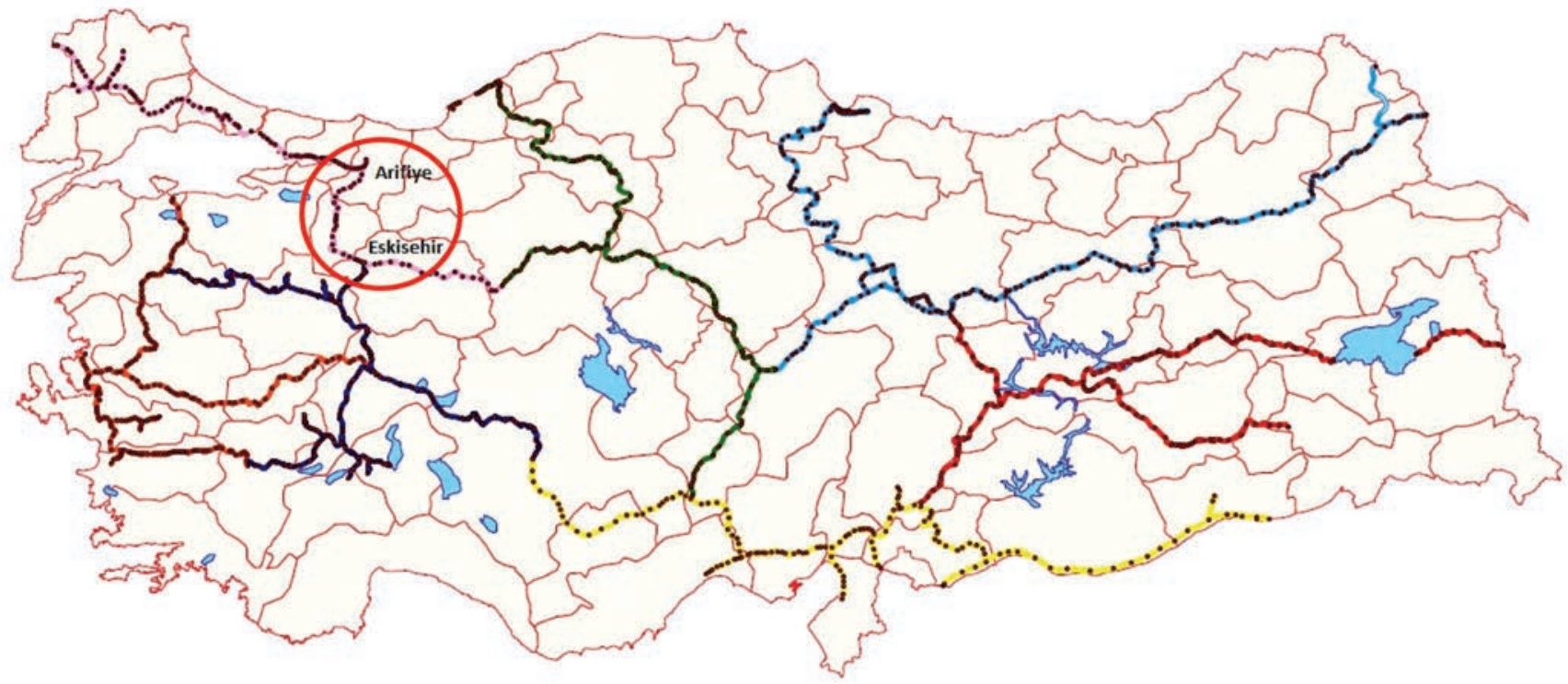

Figure 12. TCDD railway network and Arifiye-Eskisehir railway line

The system was implemented on the railway track between Arifiye and Eskisehir, which is a conventional railway about 180 kilometres in length (Figure 12). The track was divided into 720 "analytical segments" (AS), each about 250 meters in length.
The track geometry data obtained by means of no-contact and contact track recording cars were used. The no-contact track recording car named Piri Reis by TCDD is capable of measuring rail profiles and accelerations, as well as track geometry.

Table 11. Optimum M\&R activities and genetic algorithm results

\begin{tabular}{|c|c|c|c|c|c|c|c|c|}
\hline AS & Optimum M\&R & GA solution & AS & Optimum M\&R & GA solution & AS & Optimum M\&R & GA solution \\
\hline 1 & BT & BT & 31 & GC & GC & 61 & RG & RG \\
\hline 2 & BT & BT & 32 & GC & GC & 62 & $\mathrm{RG}$ & RG \\
\hline 3 & BT & BT & 33 & GC & GC & 63 & $\mathrm{RG}$ & RG \\
\hline 4 & BT & BT & 34 & GC & GC & 64 & RG & RG \\
\hline 5 & BT & BT & 35 & GC & GC & 65 & $\mathrm{RG}$ & RG \\
\hline 6 & BT & BT & 36 & GC & GC & 66 & $\mathrm{RG}$ & RG \\
\hline 7 & BT & BT & 37 & GC & GC & 67 & $\mathrm{RG}$ & RG \\
\hline 8 & BT & BT & 38 & GC & GC & 68 & IR & SFBR \& GC \\
\hline 9 & BT & BT & 39 & SFR & SFR & 69 & IR & SFBR \& GC \\
\hline 10 & BT & BT & 40 & SFR & SFR & 70 & IR & SFBR \& GC \\
\hline 11 & BT & BT & 41 & SFR & SFR & 71 & IR & SFBR \& GC \\
\hline 12 & BSR & BT & 42 & SFR & SFR & 72 & IR & SFBR \& GC \\
\hline 13 & BSR & BT & 43 & SFR & SFR & 73 & IR & SFBR \& GC \\
\hline 14 & BSR & BT & 44 & SFR & SFR & 74 & IR & SFBR \& GC \\
\hline 15 & IR & RSFR & 45 & SFR & SFR & 75 & IR & SFBR \& GC \\
\hline 16 & IR & RSFR & 46 & SFBR & SFBR & 76 & BT & BT \\
\hline 17 & IR & RSFR & 47 & SFBR & SFBR & 77 & BT & BT \\
\hline 18 & IR & RSFR & 48 & SFBR & SFBR & 78 & BT & BT \\
\hline 19 & IR & RSFR & 49 & SFBR & SFBR & 79 & BT & BT \\
\hline 20 & IR & RSFR & 50 & $\mathrm{RL}$ & $\mathrm{RL}$ & 80 & BT & BT \\
\hline
\end{tabular}


For the historical track geometry data, the no-contact track recording car measurements were used. The recorded track geometry data, consisting of profile in the left and right rails, and alignment in the left and right rails, the twist and gauge were recorded by the recording cars every $25 \mathrm{~cm}$ with the chord length of $18.9 \mathrm{~m}$. TCDD has been using portable measuring devices to collect the data concerning rails and sleepers. TCDD also has a geotechnical laboratory to test materials for track bed layers.

The results with input data consisting of 80 analytical segments corresponding to a maintenance section are summarized in Table 11. The first column represents the AS. The second column represents optimum (unconstrained) solutions produced by rule interpreter. The last column represents solutions provided by genetic algorithm.

The GA based optimisation method produced different M\&R works for about $20 \%$ of the sections shown in Table 11, as related to the optimum solution. Similarly, the GA based optimisation method produced different M\&R works for other sections. In total, the GA method produced different results for about $17 \%$ of the 720 analytical segments, when compared to the optimum solution.

As mentioned above, all necessary railway track data were used in the GA method. The GA method used probabilistic transition rules instead of deterministic rules, and it worked with a parameter set coding, rather than with parameters themselves. In addition, it searched in a population of points, rather than in a single point. Consequently, the GA optimisation method produced best solutions for the segments with the given constraints.

\section{Conclusions}

The proposed genetic algorithm based decision support system for railway track M\&R management was implemented as an optimisation tool. The developed system supports the conditionbased M\&R management system and uses all necessary trackrelated data. The system has mostly fulfilled the expectations by providing a solution to the difficult problem of maintaining track at the required quality level while keeping costs at a minimum level. Genetic algorithms, which are a strong adaptive optimization method based on biological principles, were used to optimise railway track M\&R works. Genetic algorithms were successfully applied in this study and reasonable results were obtained. Results obtained in this study show that, with an optimum choice of population size and time, a best solution in terms of track M\&R can be obtained for given constraints. More accurate solutions can be obtained with an increase in sensitivity of reference data. The developed optimisation system has a capability of renewing itself over time. The users will have a chance to change some rules or include some new rules to adapt the system to the real-life settings.

The developed system comprises conventional ballasted railway tracks. Due to the low M\&Rs, slab track system requiring much higher investments is an alternative to ballasted railway tracks. The slab track has been in widespread use in Turkey for street-running systems, light rails, and metro systems. TCDD is planning to use the slab track system in tunnels and on elevated structures for both conventional and conventional high-speed lines. This aim is going to require a combined M\&R plans involving different types of traffic (high speed railways, light rail systems, etc.) and different types of superstructure (slab tracks, etc.). Thus, the developed system is going to be adapted to the new decision environment.

\section{REFERENCES}

[1] Jovanovic, S., Guler, H., Coko, B.: Track degradation analysis in the scope of railway infrastructure maintenance management systems, GRADEVINAR, 67 (2015) 3, pp. 247-258, https://doi.org/ 10.14256/JCE.1194.2014

[2] Rashidi, M., Lemass, B., Gibson, P.: Decision support system for concrete bridge maintenance, ISCM II and EPMESC XII, PTS 1 and 2, AIP Conf. Proc., 1233 (2010), pp. 1372-1377, https://doi. org/10.1063/1.3452105

[3] Burstein, F., Holsapple, C.W.: Handbook on Decision Support Systems 1, Springer-Verlag, Berlin, pp. 21-54, 2008, https://doi. org/10.1007/978-3-540-48713-5_2

[4] Yehia, S., Abudayyeh, O., Fazal, I., Randolph, D.: A decision support system for concrete bridge deck maintenance. Adv. Eng. Software, 39 (2008) 3, pp. $202-210$.
[5] Decision Support System for Permanent Way Maintenance and Renewal (Specification for a prototype based on expert system), Report RP1, European Rail Research Institute (ERRI) - Specialist Committee D 187, Utrecht, The Netherlands, 1993.

[6] Guler, H.: Decision Support System for Railway Track Maintenance and Renewal Management, Journal of Computing in Civil Engineering, 27 (2013) 3, pp. 292-306.

[7] Deluka-Tibljas, A., Karleusa, B., Dragicevic, N.: Review of multicriteria-analysis methods application in decision making about transport infrastructure, GRADEVINAR, 65 (2013) 7, pp. 619-631.

[8] Taysi, N., Gogus, M.T., Ozakca, M.: Optimization of arches using genetic algorithm, Computational Optimization and Applications, 41 (2008) 3, pp. 377-394. 
[9] Lance, D.: The practical handbook of genetic algorithms: Applications, $2^{\text {nd }}$ edition, CRC Press, New York, USA, 2001.

[10] Grimes, C.: Application of Genetic Techniques to the Planning of Railway Track Maintenance Work, in A. Zalzala (ed.), First International Conference on Genetic Algorithms in Engineering Systems: Innovations and Applications, Sheffield, UK, Conference Publication 414, IEE, University of Sheffield, UK, 1995, https://doi. org/10.1049/сp:19951093

[11] Milajic, A., Beljakovic, D., Petronijevic, P.: Genetic algorithms for assigning tasks to construction machine operators, GRADEVINAR, 63 (2011) 8, pp. 749-755.

[12] Sakawa, M.: Genetic Algorithms and Fuzzy Multiobjective Optimization, Kluwer Academic Publishers, Massachusetts, USA, 2002, https://doi.org/10.1007/978-1-4615-1519-7

[13] Holland, J. H. (1992). "Adaptation in Natural and Artificial Systems", $2^{\text {nd }}$ edition, MIT Press, Cambridge, UK.

[14] Guler, H., Jovanovic, S., Evren, G.: Modelling railway track geometry deterioration, Proceedings of the Institution of Civil EngineersTransport, 164 (2011) 2, pp. 65 -75, https://doi.org/10.1680/ tran.2011.164.2.65

[15] Jovanovic, S., Bozovic, D., Tomicic-Torlakovic, M.: Railway infrastructure condition-monitoring and analysis as a basis for maintenance management, GRADEVINAR, 66 (2014) 4, pp. 347358, https://doi.org/10.14256/JCE.959.2013

[16] BSI British Standards. Railway applications. Track. Track geometry quality. Geometric quality levels, 2008, BS 13848: Part 5, London.

[17] Turkish State Railways (TCDD). (2014). TCDD Annual Maintenance and Renewal Report, TCDD Permanent Way Department, Ankara, Turkey.

[18] Sadeghi, J.: Development of Railway Track Geometry Indexes Based on Statistical Distribution of Geometry Data, Journal of Transportation Engineering, 136 (2010) 8, pp. 693-700, https:// doi.org/10.1061/(ASCE)0733-947X(2010)136:8(693)
[19] Patra, A.P., Söderholm, P., Kumar, U.: Uncertainty estimation in railway track life-cycle cost: A case study from Swedish National Rail Administration, Proceedings of the Institution of Mechanical Engineers - Part F - Journal of Rail \& Rapid Transit, 223 (2009) 3, pp. 285-293, https://doi.org/10.1243/09544097JRRT235

[20] International Union of Railways (UIC). UIC 712: Rail defects, $4^{\text {th }}$ Ed., Paris, 2012

[21] Kumar, S.: A Study of the Rail Degradation Process to Predict Rail Breaks, PhD thesis, Luleå University of Technology, Lulea, Sweden, 2006

[22] Evans, M., Hastings, N., Peacock, B.: Statistical Distributions, 3rd edn. John Wiley, New York, USA, 2000.

[23] Yella, S., Dougherty, M., Narendra, K.G.: Condition monitoring of wooden railway sleepers, Transportation Research Part C, 17 (2009) 1, pp. 38-55, https://doi.org/10.1016/j.trc.2008.06.002

[24] O'Connor, A.N.: Probability Distributions Used in Reliability Engineering, the Reliability Information Analysis Center (RIAC), University of Maryland, College Park, Maryland, USA, 2011.

[25] International Union of Railways (UIC). (2008). UIC 719: Earthworks and track bed for railway lines, UIC, $3^{\text {rd }}$ Ed., Paris.

[26] BSI British Standards. Aggregates for railway ballast, 2003, BS 13450, London.

[27] International Union of Railways (UIC). (2009). UIC 714: Classification of lines for the purpose of track maintenance, UIC, $4^{\text {th }}$ Ed., Paris.

[28] Patra, A.P.; Maintenance Decision Support Models for Railway Infrastructure using RAMS \& LCC Analyses, PhD thesis, Luleå University of Technology, Lulea, Sweden, 2009. 